\title{
Evaluation of White Matter Abnormalities with Diffusion-weighted Imaging in a Boy with Classical Phenylketonuria: A Case Report
}

\author{
Klasik Fenilketonürili Bir Erkek Çocukta Beyaz Cevher Anormalliklerinin Difüzyon Ağırlıkı \\ Görüntülemesi: Bir Olgu Sunumu
}

\author{
Mehmet Haydar Atalar \\ Department Of Radiology, Cumburivet University School Of Medicine, Sivas, Turkey
}

\begin{abstract}
We herein report the case of a 16-year-old mentally normal boy with phenylketonuria, who was under dietary control since infancy. Magnetic resonance (MR) imaging showed multiple superficial and deep white-matter hyperintensity in T2-weighted and proton density images. Echo-planar "trace" diffusion MR imaging revealed high signal intensity changes at the lesion sites on $b=1000 \mathrm{~s} / \mathrm{mm}^{2}$ images, initially suggesting restricted diffusion. On corresponding apparent diffusion coefficient (ADC) maps, the lesions had low signal intensity and low $A D C$ values (0.32 to $\left.0.43 \times 10^{3} \mathrm{~mm}^{2} / \mathrm{s}\right)$, in comparison with the normal frontal white matter $(0.80$ to $1.03 x$ $\left.10^{-3} \mathrm{~mm} / \mathrm{s}\right)$. This was consistent with the presence of decreased diffusion, hence cytotoxic edema.
\end{abstract}

Key words: diagnostic imaging; diagnostic techniques and procedures; diffusion-weighted imaging; magnetic resonance imaging; phenylketonurias

\section{ÖZET}

Bu yazıda, bebeklikten itibaren diyet kontrolünde olan ve mental olarak normal olan fenilketonürili 16 yașında bir erkek çocuk olguyu sunmaktayız. MRG, T2-ağırlıklı ve proton dansite görüntülerde çoklu yüzeyel ve derin ak madde hiperintensitesi gösteriyordu. Eko-planar "trace" difüzyon MR görüntülemede $b=1000 \mathrm{~s} / \mathrm{mm}^{2}$ görüntülerinde lezyon alanlarında bașlangıçta kısıtlanmıș difüzyon düșündüren yüksek sinyal intensitesi değișiklikleri tespit edildi. Karșılık gelen görünür difüzyon katsayısı (GDK) haritalarında ise lezyonların normal frontal ak maddeye $\left(0.80\right.$ to $\left.1.03 \times 10^{-3} \mathrm{~mm}^{2} / \mathrm{s}\right)$ göre düșük sinyal intensitesi ve düșük GDK değerleri (0.32 to 0.43 $\times 10^{33} \mathrm{~mm}^{2} / \mathrm{s}$ ) vardı. Bu durum, düșük difüzyon yani sitotoksik ödem ile uyumluydu.

Anahtar kelimeler: tanısal görüntüleme; tanısal teknik ve ișlemler; difüzyon ağırlıklı görüntüleme; manyetik rezonans görüntüleme; fenilketonüriler

Doc. Dr: Mehmet Haydar Atalar, Cumburivet Üniversitesi T⿰力口 Fakültesi Radyoloji AD, Kampüs 58140 Sivas - Türkiye, Tel. 03462580289 Email.mbatalar@gmail.com Gelis Taribi: 18.12.2011 • Kabul Taribi: 04.07.2012

\section{Introduction}

Phenylketonuria (PKU) is an autosomal recessive disorder caused by a deficiency of the enzyme phenylalanine hydroxylase. Affected patients develop elevated plasma and tissue levels of phenylalanine and its related ketoacids. Untreated patients usually exhibit severe mental retardation and poor motor function with characteristic T2 white matter signal abnormalities on conventional magnetic resonance (MR) images. Recently, a relatively small number of patients with PKU has been studied using diffusion-weighted imaging (DWI) ${ }^{1-4}$. Diffusionweighted imaging may provide information about the nature of parenchymal changes producing T2 changes and provide an additional quantitative MR parameter for assessing and monitoring patients with PKU.

In the present article, we report MR and DW imaging findings in a patient with classical PKU.

\section{Case report}

A 16-year-old mentally normal boy diagnosed with PKU and has been under dietary control since infancy admitted to our clinic with the initial symptoms of acute/subacute hemiparesis and headache/vomiting. PKU had been well controlled through years and the patient had not experienced difficulty in learning.

At the time of MR imaging examinations, the laboratory work up including the blood phenylalanine level of $11 \mathrm{mg} / \mathrm{dL}$ (normal range: 4-20 mg/dL) was unremarkable. 
Cranial MR imaging examination was performed by using a 1.5-T MR imaging unit (Excelart, Toshiba, Tokyo, Japan) with a standard head coil and T1weighted spin-echo (SE) (repetetion time [TR] / echo time [TE]: $400 \mathrm{msec} / 10 \mathrm{msec}$ ) and T2-weighted fast SE (TR/TE: $4400 \mathrm{msec} / 100 \mathrm{msec}$ ) and fluid attenuated inversion recovery sequence (FLAIR) images (TR/TE: $8000 \mathrm{msec} / 130 \mathrm{msec}$, inversion time [T]: $2200 \mathrm{msec}$ ), and echo-planar diffusion weighted (DWI) MR images were obtained.

On routine MR sequences, bilateral periventricular white matter was noticed to be affected. In particular, T2-weighted and FLAIR images showed symmetrically distributed high signal lesions in bilateral periventricular and subcortical white matter (Fig. $1 \mathrm{a}, \mathrm{b}$ ). The white matter abnormalities were around the frontal horns, bodies and atria, and at the occipital horns of the lateral ventricles. On the post-contrast T1-weighted images, there was no significant enhancement.

On diffusion-weighted images (single-shot spinecho echo-planar pulse sequence with b-value $=1000 \mathrm{~s} /$ $\mathrm{mm}^{2}$, superior-inferior direction of diffusion encoding gradient, TR/TE: $4000 \mathrm{msec} / 110 \mathrm{msec}$, field of view: $230 \times 230 \mathrm{~mm}$, matrix size: $128 \times 128$, number of slices: 17 , slice thickness: $5 \mathrm{~mm}$, and number of excitation: 1), high signal intensities consistent with restricted diffusion (ischemia-cytotoxic edema) were seen on the areas of increased signal intensities indicated by the T2-weighted and FLAIR images (Fig. 2).

ADC mapping (3 different b-values: $0 \mathrm{~s} / \mathrm{mm}^{2}, 500$ $\mathrm{s} / \mathrm{mm}^{2}, 1000 \mathrm{~s} / \mathrm{mm}^{2}$, and 3 orthogonally directed diffusion encoding gradients for each b-value) was performed to elucidate the cause of the increased signal intensity on the diffusion-weighted images. Automatically generated ADC maps were studied, on which the corresponding regions revealed low signal intensity. ADC values were obtained by direct reading from the maps by using electronic evaluations with region of interest (ROI), each including 16 pixels. At the lesion sites, the ADC value was between 0.32 to $0.43 \times 10^{-3} \mathrm{~mm}^{2} / \mathrm{s}$ in comparison with the ADC values of unaffected regions of the white matter ranging between 0.80 and $1.03 \times 10^{-3} \mathrm{~mm}^{2} / \mathrm{s}$. Hypointensity in ADC map indicated cytotoxic edema and restricted diffusion similar to intramyelinic edema (Fig. 3). The patient was followed with 1 -year interval.

\section{Discussion}

Phenlyketonuria is the most common congenital disorder of amino acid metabolism due to deficiency of the enzyme phenylalanine hydroxylase. Phenlyketonuria is a common "pure neurometabolic" disorder, and it has two forms, the more frequent "classical" type $1(98 \%)$ and the rare "malignant" type 2.
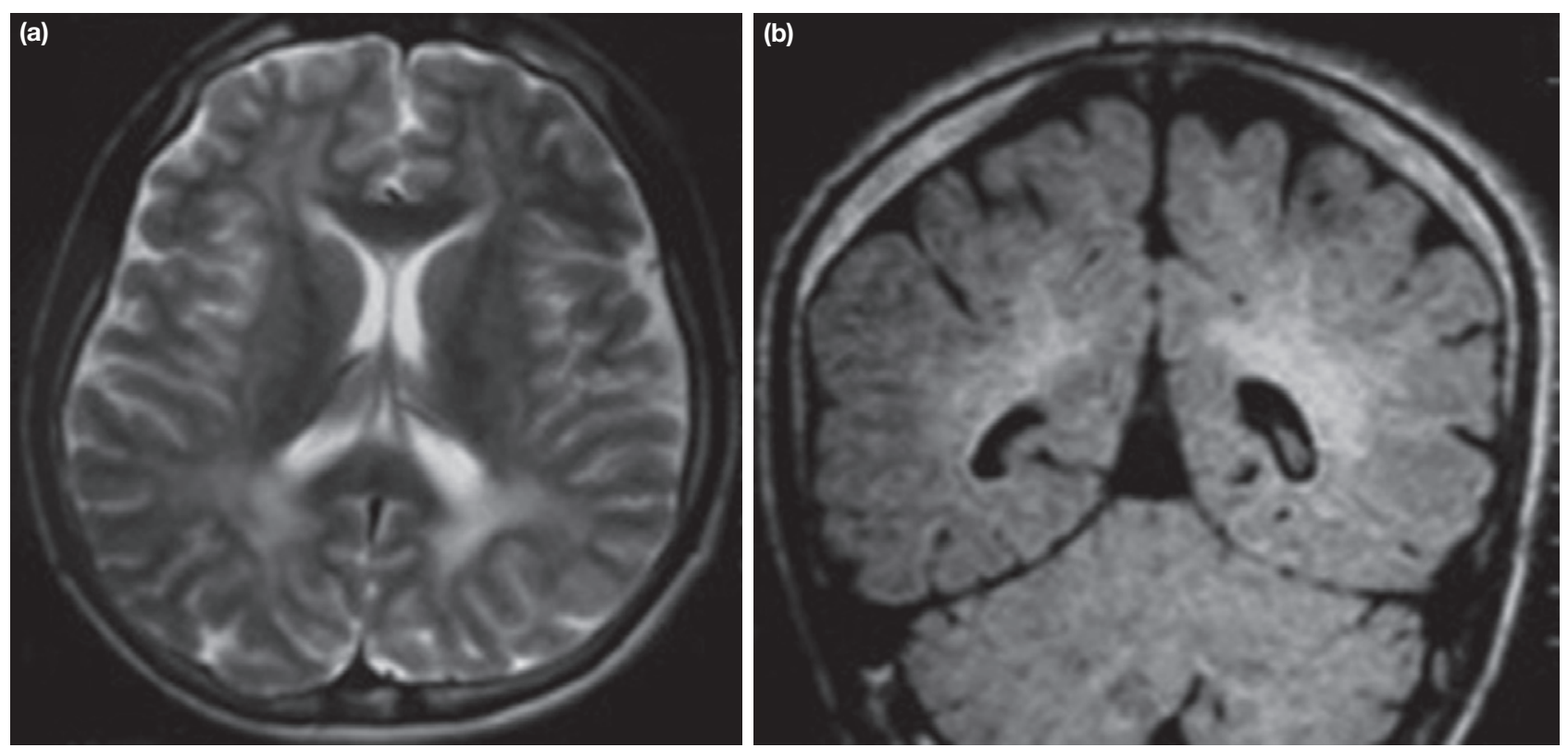

Figure 1. a, b. Axial T2-weighted (a) and coronal FLAIR (b) images reveal bilateral high-signal changes in the periventricular white matter regions. 


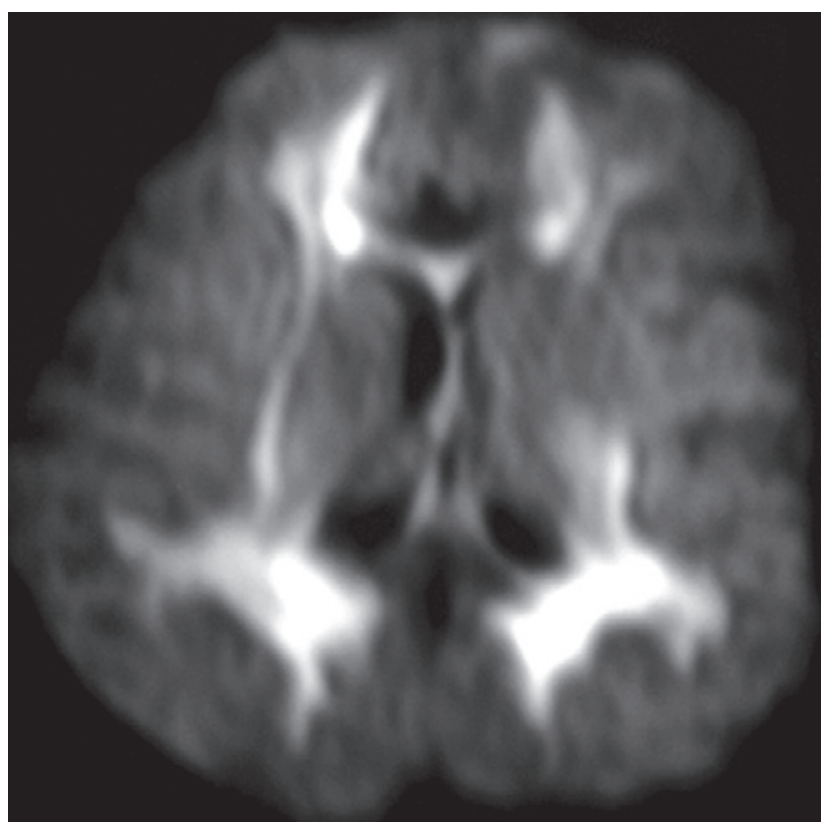

Figure 2. Trace diffusion-weighted ( $b=1000 \mathrm{smm}^{2}$ ) images reveal a restricted diffusion pattern (high signal) in the corresponding regions.

Untreated PKU patients typically develop a characteristic clinical picture that may include mental retardation, seizures, growth retardation, hyperreflexia, eczematous dermatitis, and hypopigmentation. The disease is an autosomal recessive disorder that causes a broad spectrum of clinical and metabolic phenotypes ranging from mild hyperphenylalaninemia to classic $\mathrm{PKU}^{5,6}$.

Neuropathological studies in untreated phenylketonuria patients show evidence of defective myelination (hypo and dysmyelination) and myelin maintenance (demyelination) $)^{5-7}$.

With elevated phenylalanine levels, patients with PKU generally demonstrate symmetric patchy and/ or band-like areas of enhanced signal intensity on T2-weighted MR images. The changes predominantly affect the posterior/periventricular white matter. In more severely affected patients, the lesions extend to the frontal and subcortical white matter, including corpus callosum and the area of the association fibers. The etiology of T2 hyperintensity is thought to be due to increased water content due to edema associated with myelination or gliosis ${ }^{7}$.

In a study using diffusion MRI, Phillips et al. reported the findings of three patients with phenylketonuria ${ }^{2}$. The patients had significantly restricted diffusion of

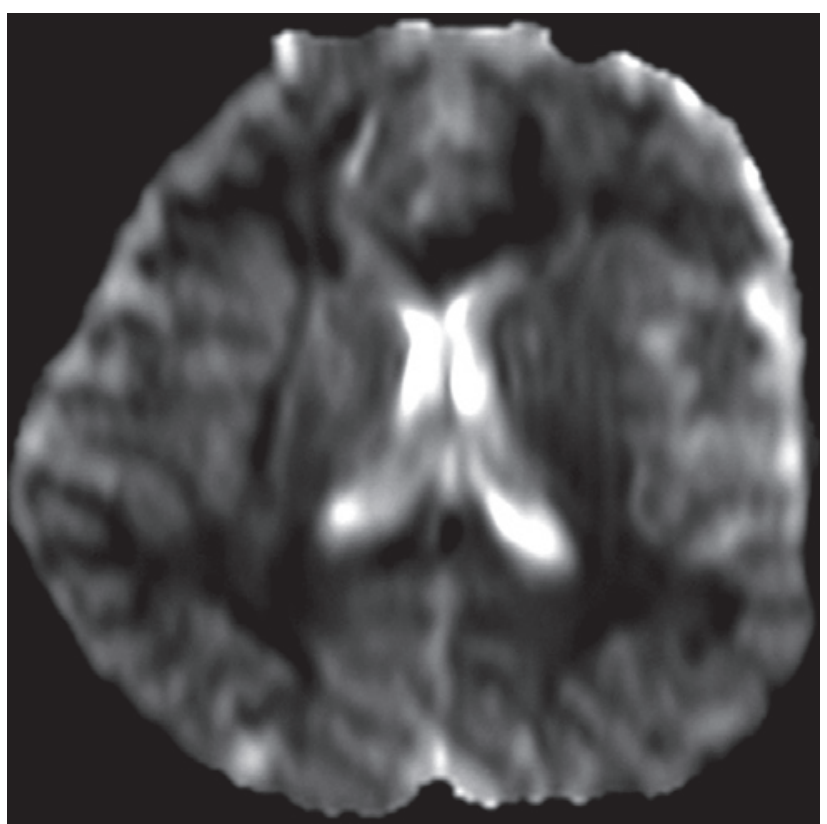

Figure 3. Corresponding ADC maps reveal low $A D C$ values of the lesions with restricted diffusion.

water molecules manifested by prominent high signal of the deep white matter on $\mathrm{b}=1000 \mathrm{~s} / \mathrm{mm}^{2}$ images in association with low signal and low ADC values on ADC maps. The ADC values ranged between 0.56 and $0.63 \times 10^{-3} \mathrm{~mm}^{2} / \mathrm{s}$. The authors concluded that, this restricted diffusion pattern reflected the impaired myelination in where the protons within the partially destroyed portions of myelin sheath might not have normal mobility ${ }^{2}$.

In a recent study using diffusion MR imaging, Kono et al. reported the findings of 21 patients with phenylketonuria ${ }^{3}$. The patients had significantly restricted diffusion of water molecules manifested by prominent high signal of the deep white matter on $\mathrm{b}=1000 \mathrm{~s} / \mathrm{mm}^{2}$ images in association with low signal and low ADC values on ADC maps. The ADC values ranged between 0.45 and $0.94 \times 10^{-3} \mathrm{~mm}^{2} / \mathrm{s}$. Kono et al., like Phillips et al., concluded that this restricted diffusion pattern reflected the impaired myelination in where the protons within the partially destroyed portions of myelin sheath might not have normal mobility.

Sener described two distinct patterns (restricted and increased diffusion patterns) on ADC maps in $\mathrm{PKU}^{8}$. It is likely that these values reflected presence of two different histopathological changes in 
phenylketonuria or reflected different stages of the same disease. In the present case, on $b=1000 \mathrm{~s} / \mathrm{mm}^{2}$ images, high signal changes consistent with a restricted diffusion pattern (cytotoxic, edematous pattern) of water molecules were evident at the sites with lesions and manifested by low signal, and low ADC values on $\mathrm{ADC}$ maps.

A number of recent diffusion MR studies have provided normal ADC values of the cerebral white matter and basal ganglia?. It seems that the accepted mean ADC value of the normal white matter is about $0.84( \pm 0.11) \times 10^{-3} \mathrm{~mm}^{2} / \mathrm{s}$. In addition the mean ADC values of the normal basal ganglia and thalami are about $0.83( \pm 0.13) \times 10^{-3} \mathrm{~mm}^{2} / \mathrm{s}$. Thus, the ADC values in the periventricular white matter of our patient with PKU (e.g. from 0.38 to $0.43 \times 10^{-3} \mathrm{~mm}^{2} / \mathrm{s}$ ) were significantly low. The finding might be related withthe impaired myelination associated with a restriction of mobility of the water molecules in the partially destroyed portions of myelin sheath, as suggested by Phillips et al'2.

In a recent experiment the transition of water from the solid to the gel state caused the signal on diffusion MRI with a higher signal in gel form on $b=1000$ $\mathrm{s} / \mathrm{mm}^{2}$ images (which should result in low ADC values $)^{10}$. Thus, an alternative explanation could be the existence of water in some form of gel status in the regions with impaired myelination.

In conclusion, the diffusion MR imaging seems to be a promising and useful sequence to evaluate the changes in the brain tissues of patients with $\mathrm{PKU}$, and probably other metabolic and neurotoxic conditions.

\section{References}

1. Dezortová M, Hájek M, Tintěra J, et al. MR in phenylketonuriarelated brain lesions. Acta Radiol 2001; 42: 459-66.

2. Phillips MD, McGraw P, Lowe MJ, et al. Diffusion-weighted imaging of white matter abnormalities in patients with phenylketonuria. AJNR Am J Neuroradiol 2001; 22: 1583-6.

3. Kono K, Okano Y, Nakayama K, et al. Diffusion-weighted MR imaging in patients with phenylketonuria: relationship between serum phenylalanine levels and ADC values in cerebral white matter. Radiology 2005; 236: 630-6.

4. Sener RN. Phenylketonuria: Diffusion magnetic resonance imaging and proton magnetic resonance spectroscopy. J Comput Assist Tomogr 2003; 27: 541-3.

5. Scriver CR. Science, medicine and phenylketonuria. Acta Paediatr Suppl 1994; 407: 11-8.

6. Pietz J. Neurological aspects of adult phenylketonuria. Curr Opin Neurol 1998; 11: 679-88.

7. Pearsen KD, Gean-Marton AD, Levy HL, et al. Phenylketonuria: MR imaging of the brain with clinical correlation. Radiology 1990; 177: 437-40.

8. Sener RN. Diffusion MRI findings in phenylketonuria. Eur Radiol 2003; 13: 226-9.

9. Sener RN. Diffusion MRI: apparent diffusion coefficient (ADC) values in the normal brain and a classification of brain disorders based on ADC values. Comput Med Imaging Graph 2001; 25: 299-326.

10. Branco G. An alternative explanation of the origin of the signal diffisuion-weighted MRI. Neuroradiology 2000; 42: 96-8. 